Supporting Information

\title{
Highly Efficient Oxygen Evolution Reaction in Rechargeable Lithium-Oxygen Batteries with Triethylphosphate-Based Electrolytes
}

Shoichi Matsuda, ${ }^{\dagger, t^{*}}$, Hitoshi Asahina ${ }^{\dagger, t}$

${ }^{\dagger}$ Center for Green Research on Energy and Environmental Materials, National Institute for Material Science, 1-1 Namiki, Tsukuba, Ibaraki 305-0044, Japan

NIMS-SoftBank Advanced Technologies Development Center, National Institute for Material Science, 1-1 Namiki, Tsukuba, Ibaraki 305-0044, Japan 


\section{Table S1}

Physical properties of electrolytes investigated in the present study

\begin{tabular}{|c|c|c|c|}
\hline Electrolyte & Conductivity & Viscosity & Density \\
& $\mathrm{mS} / \mathrm{cm}$ & $\mathrm{mPa} \mathrm{s}$ & $\mathrm{g} / \mathrm{cm}^{3}$ \\
\hline $1 \mathrm{M} \mathrm{LiNO}_{3}$ in TEP & 2.6 & 3.8 & 1.11 \\
\hline $3 \mathrm{M} \mathrm{LiNO}_{3}$ in TEP & 1.1 & 26.9 & 1.18 \\
\hline $1 \mathrm{M} \mathrm{LiTFSI}$ in TEP & 5.1 & 3.6 & 1.17 \\
\hline $1 \mathrm{M} \mathrm{LiTFSI}+1 \mathrm{M} \mathrm{LiNO}_{3}$ in TEP & 2.4 & 13.1 & 1.22 \\
\hline
\end{tabular}


a
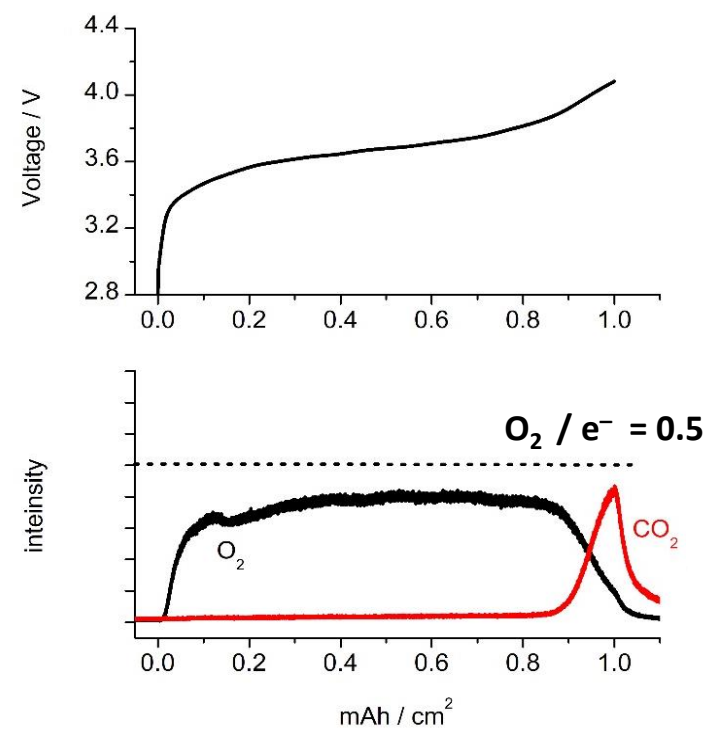

b
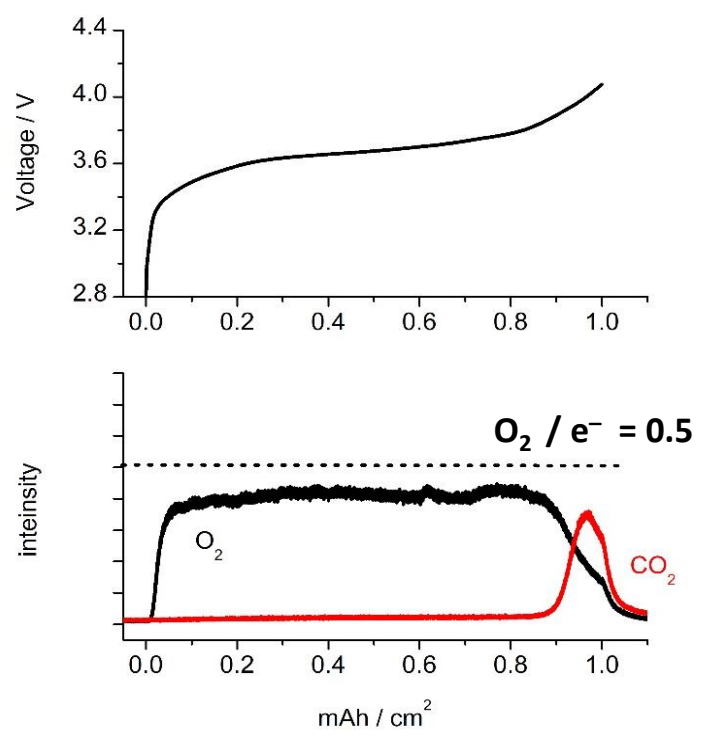

Figure S2

In situ $\mathrm{MS}$ analysis of $\mathrm{Li}-\mathrm{O}_{2}$ cells with electrolytes of (a) $1 \mathrm{M} \mathrm{LiNO}_{3}$ in TEGDME and (b) $3 \mathrm{M} \mathrm{LiNO}_{3}$ in TEGDME. The experiments employed a current density of $0.1 \mathrm{~mA} / \mathrm{cm}^{2}$. The theoretical value of oxygen evolution efficiency is shown as dotted line. 


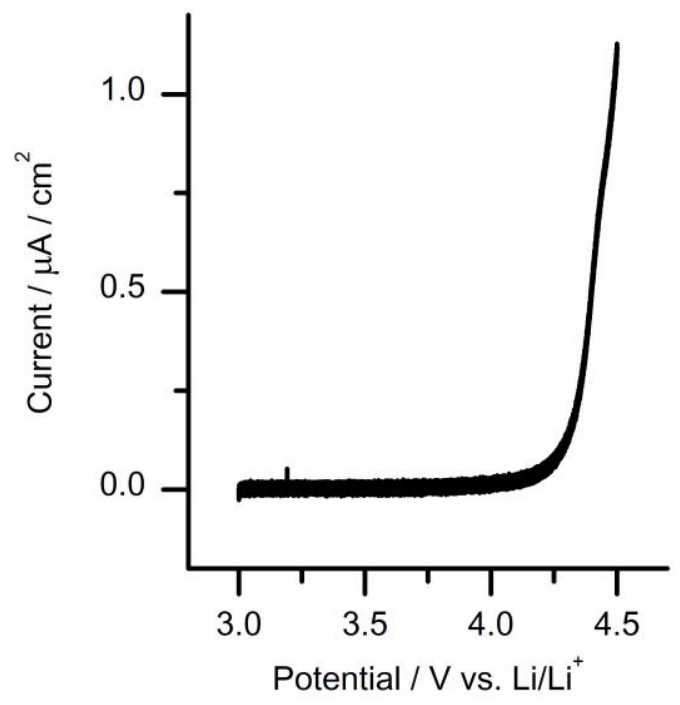

\section{Figure S3}

Liner sweep voltammogram of electrochemical cells with electrolytes of $3 \mathrm{M} \mathrm{LiNO}_{3}$ in TEP. The experiments employed a current density of $0.003 \mathrm{mV} / \mathrm{s}$. 

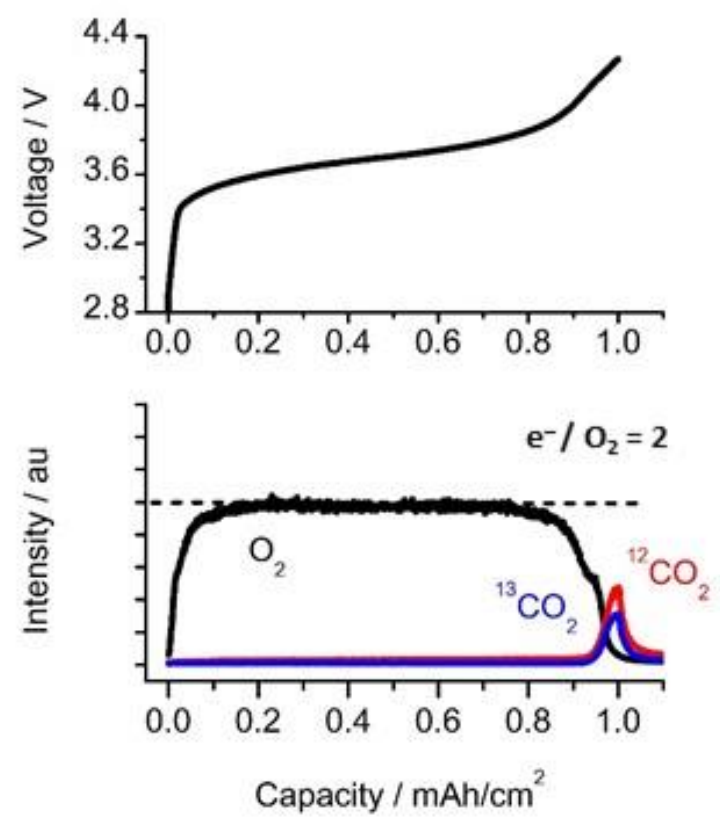

\section{Figure S4}

In situ MS analyses of $\mathrm{Li}-\mathrm{O}_{2}$ cells with ${ }^{13} \mathrm{C} /{ }^{12} \mathrm{C}$ composite electrode using $3 \mathrm{M} \mathrm{LiNO}_{3}$ in TEP as electrolyte. The experiments employed a current density of $0.1 \mathrm{~mA} / \mathrm{cm}^{2}$. The theoretical value of oxygen evolution efficiency is shown as dotted line. 

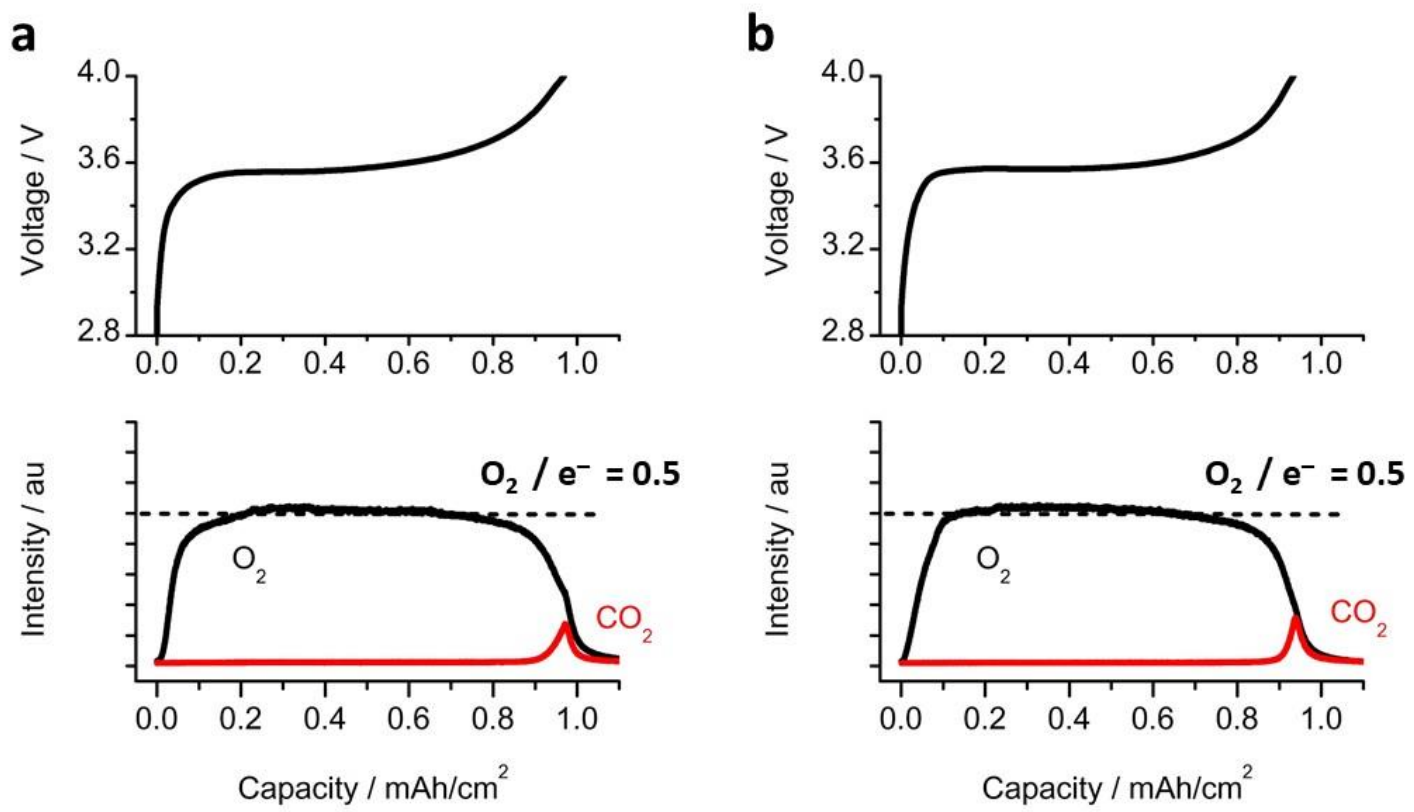

Figure S5

In situ MS analysis of $\mathrm{Li}-\mathrm{O}_{2}$ cells with electrolytes of $3 \mathrm{M} \mathrm{LiNO}_{3}$ in TEP with (a) $10^{\text {th }}$ and (b) $20^{\text {th }}$ charging process. The experiments employed a current density of $0.1 \mathrm{~mA} / \mathrm{cm}^{2}$. The theoretical value of oxygen evolution efficiency is shown as dotted line. 

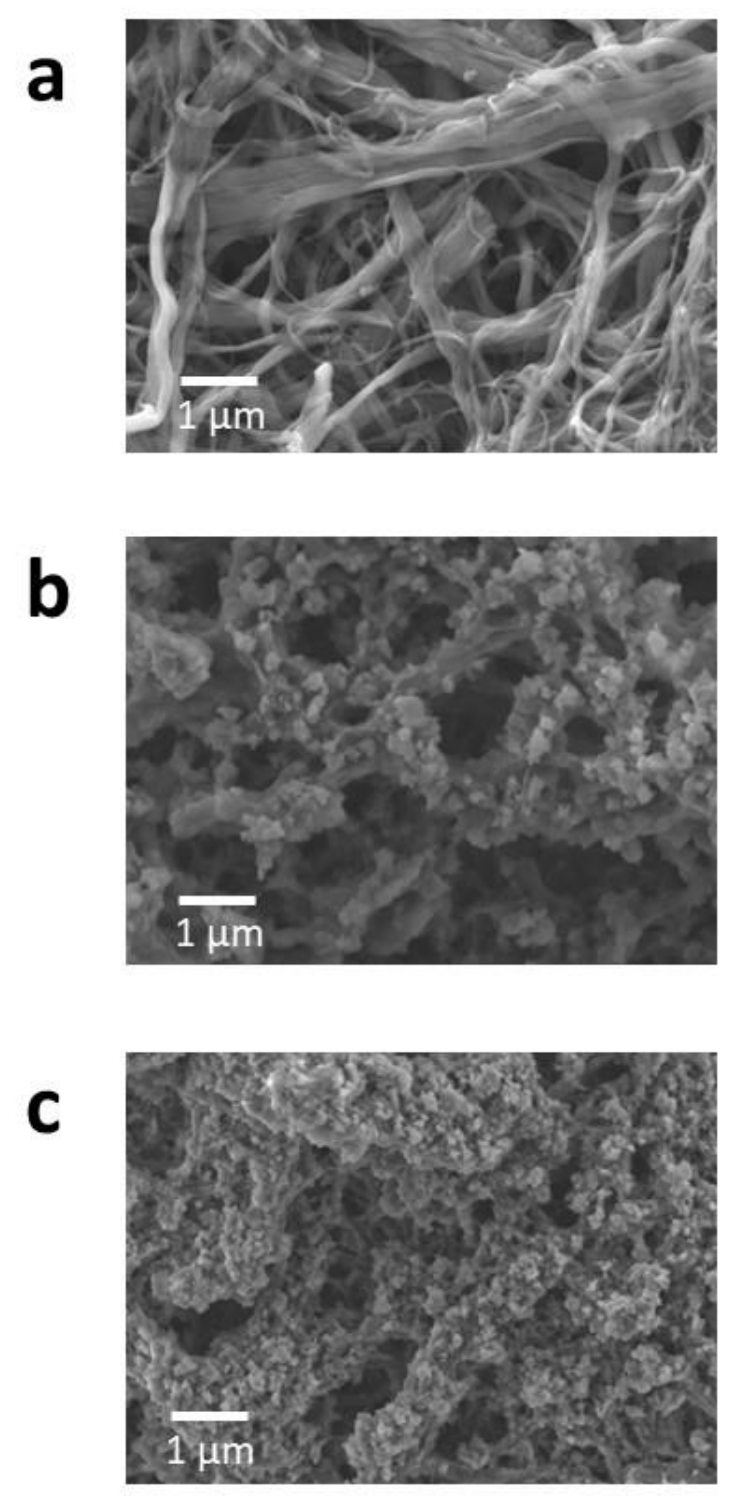

\section{Figure S6}

SEM analysis of the carbon electrodes removed from the $\mathrm{Li}-\mathrm{O}_{2}$ cells with the electrolyte of

$3 \mathrm{M} \mathrm{LiNO}_{3}$ in TEP (a) before, (b) after $10^{\text {th }}$ and (c) after $40^{\text {th }}$ charging processes. 

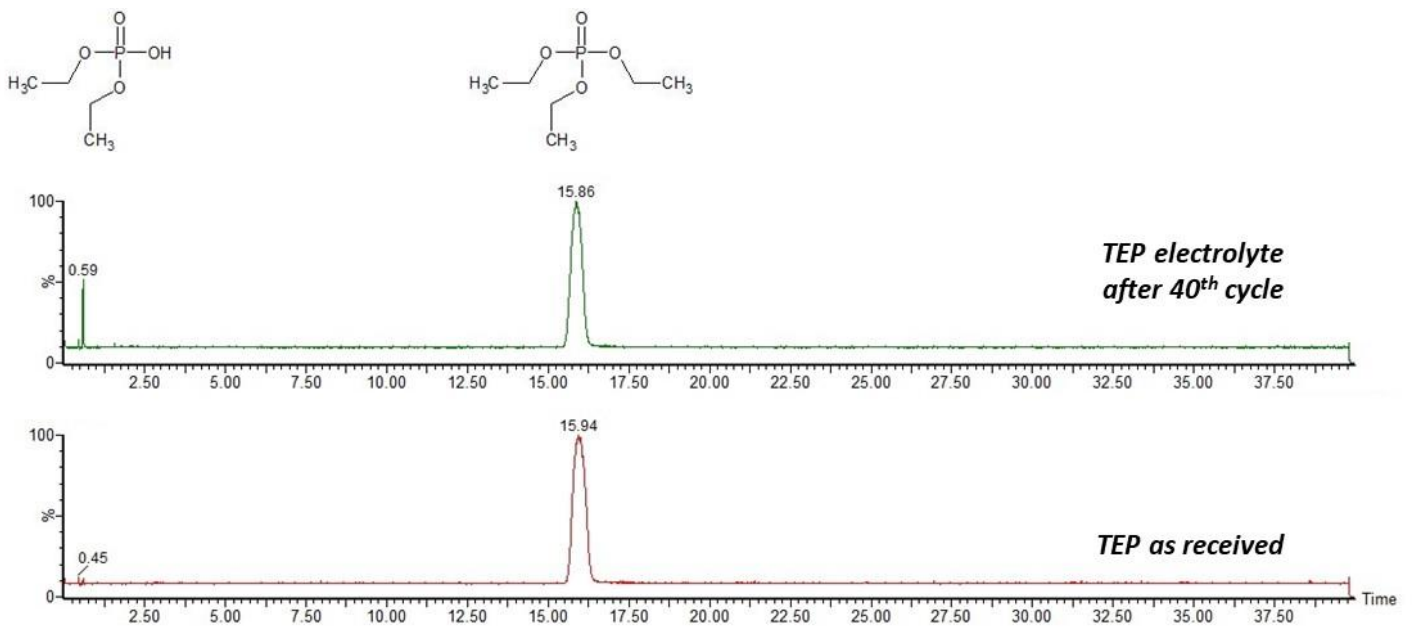

\section{Figure S7}

LC-MS analysis of $3 \mathrm{M} \mathrm{LiNO}_{3}$ in TEP electrolyte removed from the $\mathrm{Li}-\mathrm{O}_{2}$ cell after the $40^{\text {th }}$ charging process. 


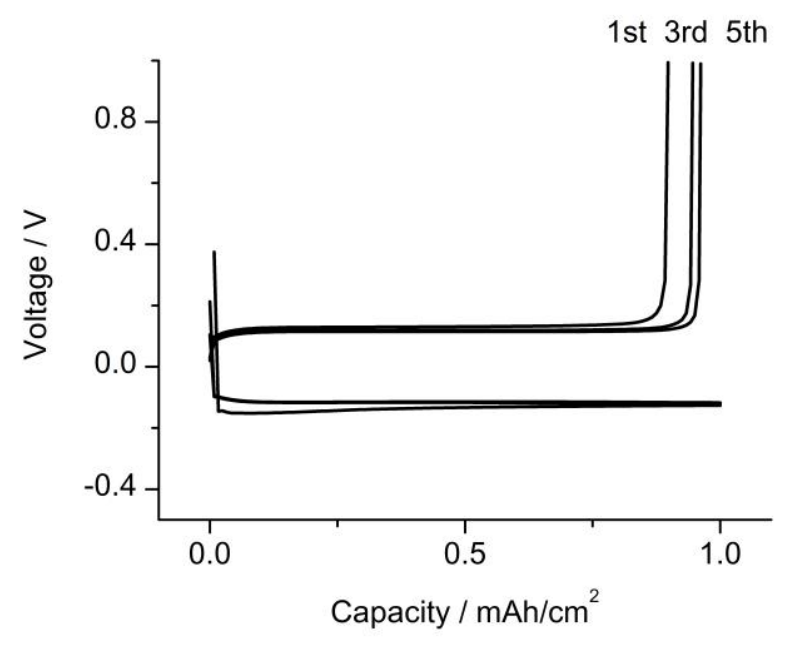

Figure S8

Li deposition/dissolution cycles of $\mathrm{Ni} / \mathrm{Li}$ cell with electrolyte of $3 \mathrm{M} \mathrm{LiNO}_{3}$ in TEP. The current density was set to $0.5 \mathrm{~mA} / \mathrm{cm}^{2}$ with capacity limitation of $1.0 \mathrm{mAh} / \mathrm{cm}^{2}$. 

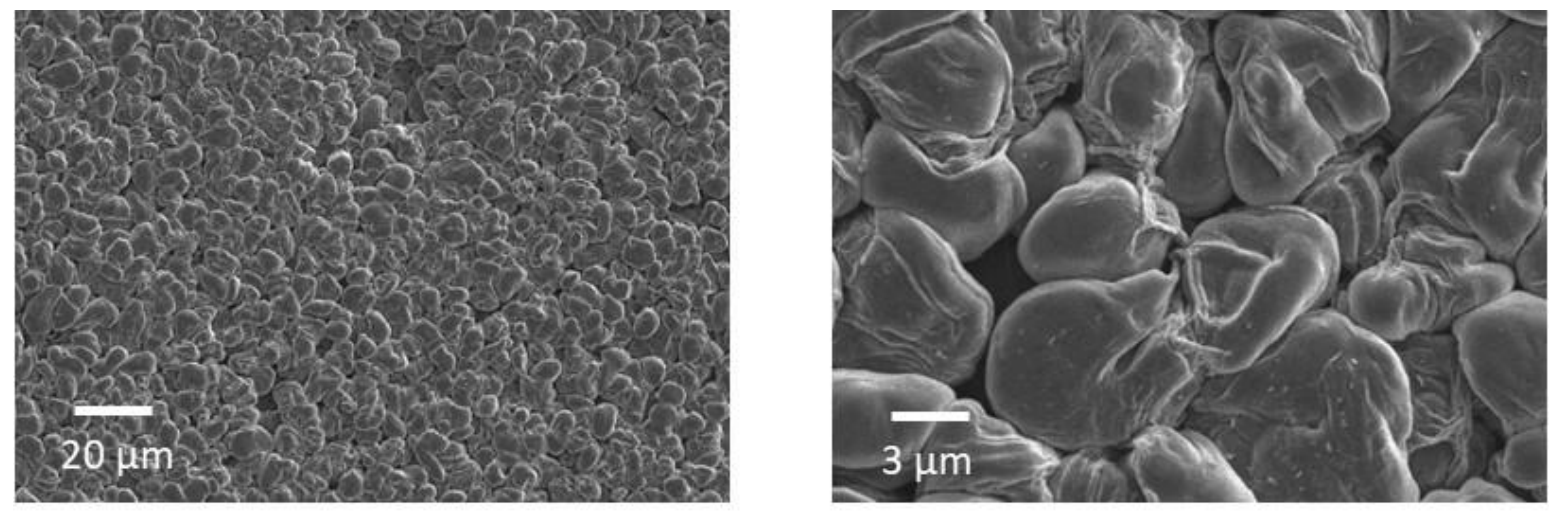

\section{Figure S9}

SEM image of the $\mathrm{Li}$ metal electrode that taken out from $\mathrm{Li}-\mathrm{O}_{2}$ cell with electrolyte of $3 \mathrm{M}$ $\mathrm{LiNO}_{3}$ in TEP after the $40^{\text {th }}$ discharge/charge cycle. 